\title{
Inovasi Teknologi Digital Diplomasi: Pembuatan Aplikasi dan Sistem Profiling Digital Diplomasi Menuju Techplomacy $5.0 \mathrm{G}$
}

\author{
https://doi.org/10.32509/am.v4i1.1362
}

\section{Taufiqurokhman $^{1}$, Danny Kunto Wibisono ${ }^{2}$, Alif Ariaputra ${ }^{3}$, Aldi Satria ${ }^{4}$, Elena Libratia Surya $^{5}$, Bernadette Ingrid Mastail Budhiadi ${ }^{6}$}

\author{
${ }^{1}$ Dosen, Fakultas Ilmu Sosial Dan Politik , Universitas Prof. Dr. Moestopo (Beragama), \\ Jalan Hang Lekir I No 8 Jakarta Pusat 10270, Indonesia \\ 2,3,4,5,6 Mahasiswa, Program Studi Hubungan Internasional Fakultas Ilmu Sosial Dan Politik, \\ Universitas Prof. Dr. Moestopo (Beragama), Jalan Hang Lekir I No 8 Jakarta Pusat 10270, Indonesia
}

Email Koresnpondensi: taufiqurokhman@dsn.moestopo.ac.id

\begin{abstract}
This article is a Written Idea Student Creativity competition, Directorate of Learning and Student Affairs, Directorate General of Higher Education, Ministry of Education and Culture of Indonesia 2021. Discussing Techplomacy Innovation, by creating applications and a diplomacy digital profiling system towards 5.0G. The purpose of writing is to make it easier for Indonesian diplomats to conduct digital diplomat profiling for destination countries. Namely providing social, economic, cultural, political, legal, education, health, defense and security information, energy, technology, environmental food, and socio-cultural tourism of the destination country. Descriptive qualitative methodology, which explains various summaries of information and analysis of the information obtained to create an application system and digital technology profiling that can be used by the international relations study program or the Ministry of Foreign Affairs of the Republic of Indonesia. The result of the research, diplomacy technology (Techplomacy) with application and profiling systems makes it easier for Indonesian diplomats to conduct digital diplomat profiling of destination countries. This is because the application and profiling system summarizes various social, economic, cultural, political, legal, educational, health, defense and security information, energy, technology, environmental food, and socio-cultural tourism from the destination country.
\end{abstract}

Keywords: Digital Diplomacy Technology Innovation, Making Applications and Diplomacy Digital Profiling Systems, Towards 5.0G Techplomacy

\begin{abstract}
Abstraksi - Artikel ini adalah perlombaan Kreatifitas Mahasiswa Gagasan Tertulis, Direktorat Pembelajaran dan Kemahasiswaan Ditjen Pendidikan Tinggi Kementerian Pendidikan Kebudayaan Indonesia 2021. Membahas, Inovasi Techplomacy, dengan cara membuat aplikasi dan sistem profiling digital diplomasi menuju 5.0G. Tujuan penulisan, memudahkan para diplomat Indonesia melakukan profiling diplomat digital untuk negara tujuan. Yaitu memberikan informasi sosial, ekonomi, budaya, politik, hukum, pendidikan, kesehatan, pertahanan keamanan, energi, teknologi, pangan lingkungan, serta sosial budaya pariwisata dari negara tujuan. Metodologi kualitatif deskriftif, yaitu menjelaskan berbagai rangkuman informasi berikut analisa terhadap informasi yang didapat untuk membuat sistem aplikasi dan profiling teknologi digital yang bisa dipergunakan oleh program studi hubungan internasional atau Kementerian Luar Negeri Republik Indonesia. Hasil penelitian, teknologi diplomasi (Techpllomacy) dengan system aplikasi dan profiling memudahkan para diplomat Indonesia melakukan profiling diplomat digital negara tujuan. Karena, aplikasi dan sistem profiling merangkum berbagai informasi sosial, ekonomi, budaya, politik, hukum, pendidikan, kesehatan, pertahanan keamanan, energi, teknologi, pangan lingkungan, serta sosial budaya pariwisata dari negara tujuan.

Kata Kunci: Inovasi Teknologi Digital Diplomasi, pembuatan Aplikasi dan Sistem Profiling Digital Diplomasi, Menuju Techplomacy 5.0G
\end{abstract}

\section{PENDAHULUAN}

Perkembangan digital diplomasi di Indonesia, saat ini, mengalami masa perkembangan pesat di era globalisasi dunia, seperti yang disebutkan oleh Presiden Republic of Macedonia, Boris Trajkovski 
(David Bollier, The Rise Of Netpolitik. How the Internet Is Changing International Politics and Diplomacy (Washington: The Aspen Institute, (2003, 5), yang mengatakan, "Power in the global information society depends less on territory, military power, and natural resources. Rather, information, technology, and institutional flexibility have gained importance in international relations. The power of knowledge, beliefs, and ideas are the main tools of political actors in the efforts to achieve their goals.". Sedang, Mansbach, (R W. Mansbach, "International Relations and Information Technology", International Relations, Vol. II, Encyclopedia of Life Support Systems (EOLSS). Diakses pada 14 Desember 2016, http://www.eolss.net/sample-chapters/c14/e1-35-0303.pdf), bukunya berjudul, International Relations and Information Technology, mengatakan internet, bersamaan dengan inovasi bidang teknologi, telah menurunkan posisi teritori (wilayah) kedaulatan negara. Sebuah konsepsi, bahwa batas-batas negara tidak lagi ditentukan oleh batasan fisik. Ditambahkan Wikileaks, Lihat, R W. Mansbach, "International Relations and Information Technology", International Relations, Vol. II, Encyclopedia of Life Support Systems (EOLSS). Diakses pada 14 Desember 2016, http://www.eolss.net/sample-chapters/c14/e1-35-03-03.pdf.). Menjelaskan, kejadian Arab Spring, semakin memperlihatkan pentingnya peran teknologi dan informasi (ICT) dalam politik internasional. Yaitu, adanya fenomena gerakan radikal yang menjalankan pola rekrutmen secara digital, dilihat sebagai bentuk penggunaan teknologi dan informasi. Saat ini, penggunaan teknologi dan informasi, sangat penting dalam politik internasional, dan menjadikan sebagai diplomasi. Sehingga, tidak lagi hanya bergantung pada kekuatan militer ataupun luas teritori. Tetapi, menjalankan bentuk diplomasi yang menekankan pada aspek teknologi dan informasi berbasis digital.

Perkembangan teknologi informasi dan komunikasi (ICT) digital, telah mengubah paradigma interaksi sosial dan hubungan internasional antar aktor. Saat Facebook, Twitter, Reddit, TikTok, Google dan Youtube mengeluarkan kebijakan guna meredam kekacauan dan saling klaim menang di Pemilihan Umm Presiden Amerika Tahun 2020. Yaitu, pertarungan antara Presiden petahana Donald Trump dengan penantangnya yang menang, Presiden Joe Biden. Begitu juga, Pemilihan Presiden, Dua Periode masa Pemerintahan Joko Widodo, Tahun 2014 dan 2019. Dimana, peran media sosial dan media manstream memiliki pengaruh yang sangat besar. Selain, pola aktivitas media sosial untuk di kedutaan besar setiap negara Amerika dan Eropa, saat ini, telah mengubah cara diplomasi dan negosiasi menggunakan media digital atau diplomasi siber, (Wahyu Chandra Aminuddin, Penerapan Diplomasi Digital Amerika Serikat Melalui Kebijakan 21st Century Statecraft Pada era Kepemimpinan Barrack Obama Tahun 2009- 2017, diunggah dari, http://repository.umy.ac.id/bitstream/handle/123456789/30171/NASKAH\%20PUBLIKASI.pdf?seque nce $=11 \&$ isAllowed $=y$ ).

Kenyataan sekarang ini, pembangunan opini, yang mendukung misi luar negeri, negara Amerika Serikat, dilakukan melalui internet dan televisi yang berlangsung secara massif. Amerika Serikat, menyusun propaganda secara terstruktur dan rapi. Sehingga, mendukung usaha pencapaian kepentingan nasionalnya di tataran internasional melalui diplomasi digital. Sedangkan, pelaksanaan diplomasi digital atau techplomacy di Indonesia, menurut Tantowi Yahya, (Lihat, Tantowi Yahya, "Digital Diplomacy, Sebuah Kebutuhan Mendesak", Jumat, 22 April 2016, diakses pada tanggal 14 Desember 2016, http://news.detik.com/kolom/d-3194614/digital- diplomacy-sebuah-kebutuhanmendesak), diplomasi kawasan Indonesia tidak pernah lepas dari apa yang disebut sebagai diplomasi digital. Diplomasi digital dimaksud, berupa 'serangan' negara lain. Contohnya, pada peristiwa 'Bali Nine', tanggal, 29 April 2015, yaitu penyelundupan heroin seberat 8,2 $\mathrm{kg}$ oleh sembilan orang warga Australia, (Merdeka.com, Empat ancaman Australia bila RI eksekusi gembong narkoba Bali Nine, https://www.merdeka.com/dunia/empat-ancaman-australia-bila-ri-eksekusi-gembong-narkoba-balinine.html. Dikutip Tanggal, Senin, 16 Februari 2015 06:25), yang akan dieksekusi hukuman mati (bandar narkotika) di Nusakambangan, Indonesia. Semula, Australia melakukan strategi lobi resmi, melibatkan pemerintahan kedua negara untuk menyelamatkan Bali Nine, namun gagal. Akhirnya, pemerintah Australia menggunakan diplomasi digital (elektronik), melalui media, seperti pemerintah dan warga Australia mengancam akan memboikot pariwisata di Bali. Jika eksekusi hukuman mati, terhadap tersangka Bali Nine dilakukan. Bahkan, menteri luar negeri Australia, Julia Bishop dan Senator Independen Jacqui Lambiea, mengancam akan memberhentikan bantuan internasional sumbangan bencana Tsunami ke Indonesia sebesar Rp 1 Triliun, jika hukuman mati tetap dialaksanakan. 
Penggunaan techplomacy, (The Convertation, Era baru diplomasi digital dan mengapa Indonesia harus menyambutnya? https://theconversation.com/era-baru-diplomasi-digital-dan-mengapaindonesia-harus-menyambutnya-90128. Dikutip tanggal 8 Februari 2021), di Indonesia, minimal membutuhkan informasi 10 tahun terakhir bagi para diplomat yang akan menjalankan tugasnya. Peningkatan teknologi techplomacy, seiring dengan fenomena diplomasi digital kedepan yang akan semakin berkembang pesat, dibuktikan dengan adanya data Tahun 2019 dari Kementerian Luar Negeri Indonesia yang memiliki, 288 akun Facebook, 200 lebih akun Twitter, 125 saluran Youtube dan Instagram serta media online lainnya, terhadap negara-negara lain. Dikuatkan oleh hasil penelitian Universitas Gajah Mada Center for Digital Society, menempatkan Indonesia di peringkat ke-9 diantara 203 negara untuk kegiatan diplomasi digital. Techplomacy, digunakan untuk menyebarluaskan informasi, kegiatan propaganda, kegiatan kontra propaganda dan kegiatan diplomasi lainya yang sifatnya dari internal ke eksternal. Kegiatan penghimpunan informasi dari eksternal ke internal dalam kaitanya kegiatan diplomasi tidak banyak dilakukan atau mungkin dilakukan secara tertutup dan manual untuk mempelajari setiap aktor hubungan internasional. Sehingga, setiap duta besar dan komponen pendukungnya dengan mudah mempelajari isu terkini terhadap aktor hubungan internasional di negara. Dimana keberadaan duta besar, dapat dengan mudah dipelajari, tentang bagaimana persepsi, fakta dari setiap aktor terhadap negara dan informasi strategis serta terkini dari negara domisili kedutaan dan isu-isu terkini yang sedang berkembang.

Atas dasar tersebut, penelitian ini bermaksud mendeskripsikan dan mengeksplorasi penelitian tentang, "Inovasi Teknologi Digital Diplomasi: Pembuatan Aplikasi Dan Sistem Profiling Digital Diplomasi Menuju Techplomacy 5.0G" menjadi sebuah artikel dalam Pekan Kreatifitas Mahasiswa Gagasan Tertulis (PKM-GT), Tahun 2021 yang diselenggarakan Direktorat BELMAWA, Kementerian Pendidikan Republik Indonesia. Sedangkan identifikasi permasalahan tranformasi inovasi profiling diplomat digital technplomacy menuju 5.0G adalah bagaimana; (1) seorang diplomat Indonesia yang baru bertugas, dapat mengumpulkan informasi terkait isu dan profil aktor hubungan internasional di negara tempat bertugasnya; (2) dapat menghimpun informasi isu-isu terkait aktor dan isu persektor, bidang sosial, ekonomi, budaya, politik, hukum, pendidikan, kesehatan, pertahanan keamanan, energi, teknologi, pangan lingkungan, serta sosial budaya pariwisata yang akan dicrawling oleh machine learning dan artificial intelligence (AI), dan bidang dihimpun sebagian secara manual dari internet dan sosial media dan media online; (3) seorang diplomat Indonesia, dapat menghilangkan kendala untuk dapat memilah dan memilah informasi, isu-isu aktor hubungan internasional, terkait sentimen positif dan sentimen negatif terhadap negaranya untuk keperluan bernegosiasi atau diplomasi untuk kepentingan bangsa dan negara.

\section{METODE PELAKSANAAN}

Metodologi penelitian yang digunakan dalam penulisan artikel ini adalah kualitatif, dengan disaint penelitian deskriptif. Yaitu menjelaskan bagaimana system profiling dan aplikasi Techplomacy digital era 5.0G digambarkan dengan langkah-langkah seperti di bawah ini:

1. Melakukan analisis situasi berupa: membuat kerangka sIstem aplikasi dan profiling teknologi diplomasi menggunakan 5.0G bagi para diplomat di Indonesia.

2. Melakukan observasi lapangan dan wawancara kepada para stakeholder yang diperkirakan akan menggunakan tecplomacy di Indonesia, sehingga akan terpetakan dari hasil observasi akan pentingnya alat aplikasi dan profiling techplomacy.

3. Mengidentifikasi berbagai informasi dan permasalahan, pembatasan masalah dan rumusan masalah, serta memberikan solusi terhadap akan pentingnya techplomacy bagi para stakeholder aplikasi dan system profiling di Program Studi Hubungan Internasional atau untuk kementerian Luar Negeri di Indonesia.

4. Melalukan hasil analisis situasi permasalahan yang ada terhadap akan kebutuhan teknologi digatal diplomasi bagi para diplomat di Indonesia

5. Melaksanakan sosialisasi terhadap akan pentingnya teknologogi Diplomasi (techplomacy) bagi para stakeholder yang nantinya akan menggunakan aplikasi ini.

6. Melakukan evaluasi kegiatan dan monitoring, dengan mengukur tingkat pengetahuan dan sikap para pengguna aplikasi techplmasi bagi para diplomat di Indonesia setelah mengikuti kegiatan sosialisasi system aplikasi dan profiling techplomcy. 


\section{HASIL DAN PEMBAHASAN}

Hasil pembahasan dari Inovasi Teknologi Digital Diplomasi: Pembuatan Aplikasi Dan Sistem Profiling Digital Diplomasi Menuju Techplomacy 5.0G adalah memudahkan para diplomat Indonesia melakukan profiling diplomat digital negara tujuan. Karena, aplikasi dan sistem profiling merangkum berbagai informasi sosial, ekonomi, budaya, politik, hukum, pendidikan, kesehatan, pertahanan keamanan, energi, teknologi, pangan lingkungan, serta sosial budaya pariwisata dari negara tujuan.

Selain itu, aplikasi ini akan sangat memiliki manfaat dalam beberapa hal, yaitu: (1) mempelajari profil, isu-isu terkait dengan negara tempatnya bertugas, membuat ringkasan setiap isu dan aktor-aktor yang ada secara cepat, terstruktur dan memiliki kemampuan analisis terkait aktor dan isu hubungan internasional; (2) menghimpun data dan informasi dari eksternal yang bersumber dari internet, sosial media, koran digital untuk membuat kategori aktor, profil aktor, isu persektor sebagai sumber kebijakan diplomasi; (3) mendefinisikan isu-isu terkait sentimen negatif dan sentimen positif yang disampaikan para aktor hubungan internasional yang dapat dipantau secara periodik (menit, jam, hari, minggu dan bulan) yang bersumber dari internet, sosial media.

Hasil urgensi dari penelitian ini, sesuai judulnya, Inovasi Teknologi Digital Diplomasi: Pembuatan Aplikasi Dan Sistem Profiling Digital Diplomasi Menuju Techplomacy 5.0G. Maka penelitian ini, dipandang penting dan mendesak diperlukan Pemerintah Indonesia, khususnya Kementerian Luar Negeri, paling tidak atas dasar dua hal, yaitu: Pertama, argumen bersifat teoretikal-konseptual. Dimana masih minimnya kajian dalam disiplin Ilmu Hubungan Internasional yang secara utuh mengkonseptualisasikan antara studi hubungan internasional dengan perkembangan digitalisasi informasi, terutama terkait dengan kemampuan negara, sebagai aktor utama dalam menjalankan diplomasi dan negosiasi sebagai salah satu instrumen kebijakan politik luar negeri.

Kedua, penelitian ini bersifat empirikal dan penting. Karena, dapat memberikan gambaran pada pemerintah mengenai kondisi kesiapan lembaga atau kementerian di Indonesia. Dalam mengartikan dan menjalankan diplomasi digital. Kajian ini juga berupaya menggali lesson learned kedutaan besar negara lain yang telah melakukan diplomasi digital sebagai instrumen kebijakan politik luar negerinya. Sehingga hasil penelitian ini memang sifatnya sangat mendesak, sebagai langkah untuk mentransformasi strategi diplomasi Indonesia di era digital dengan aplikasi dan sistem profiling terhadap negara tujuan bagi para diplomat yang bertugas.

Hasil penelitian, menyebutkan ada empat aspek spesifik yang terkandung dalam penelitian ini, yaitu: (1) dapat melihat perkembangan kedepan (Futuristik dan visioner) bagi perkembangan teknologi digital diplomasi di Indonesia menuju techplomacy 5.0G; (2) pembuatan aplikasi dan sistem profiling digital diplomasi dibutuhkan jangka waktu panjang dan relevan di menuju techplomacy 5.0G; (3) pembuatan aplikasi dan sistem profileng, sangat realistik dilaksanakan; (4) aplikasi dan sistem profiling teknologi diplomasi digital memiliki dampak secara sistemik serta bersifat dan berskala masif, Karena sumber informasi akan sangat mudah didapatkan dan dipelajari. Sehingga Tugas Dan Fungsi mereka sebagai Diplomat akan dapat dijalankan dengan baik.

Target temuan hasil penelitian adalah: (1) memudahkan dan menguatkan proses pengambilan regulasi atau kebijakan di Kementerian Luar Negeri RI, terkait aplikasi dan sistem diplomasi digital, (2) menghimpun berbagai informasi dari aktivitas diplomasi digital yang berdasar pada aplikasi dan sistem profiling diplomasi digital dilakukan Kementerian Luar Negeri Indonesia, khususnya melalui Facebook, Twitter, Youtube, Instagram dan media sosial lainya, (3) memberikan peluang dan tantangan bagi Indonesia dalam melakukan diplomasi digital, berbasis pada aplikasi dan sistem profiling diplomasi digital.

Dari elemen-elemen tersebut diharapakan mampu menjawab berbagai kesiapan Indonesia dalam konteks pelaksanaan diplomasi digital sebagai upaya pencapaian kepentingan nasional secara keseluruhan. Sedangkan luaran kongkrit yang diharapkan dari penelitian adalah: Artikel Jurnal. Dimana penelitian ini dapat menghasilkan artikel jurnal yang dipublikasikan dalam jurnal nasional atau jurnal internasional (salah satu).

Dalam pembahasan hasil penelitian terhadap Teknologi Diplomasi, melalui system aplikasi dan profiling (Techplomacy) menuju 5.0G dalam perubahan sosial masyarakat dunia yang terjadi saat ini, akan mendorong jangkauan informasi yang sangat luas, sebagian atau bahkan seluruh teknologi dalam berbagai bentuk informasi. Sehingga penggunaan techplomacy menjadi sebuah keharusan dalam diplomatik digital Indonesia. 
Akan memberikan dampak kecerdasan buatan dan otomatisasi pada masa depan pekerjaan, seperti menyangkut data perlindungan informasi pribadi, media sosial yang digunakan dalam dialog demokrasi dan pemilu, dunia maya yang dijaga dengan keamanan cyber, model bisnis untuk sistem perpajakan yang digital, dan cryptocurrency pada arsitektur keuangan global. Tren ini jika dikelompokkan bersama menjadi 'Revolusi Industri Kelima' yang bersifat internasional, melampaui batas dengan kecepatan yang belum pernah terjadi sebelumnya, mengubah hampir semua sektor masyarakat, dan berdampak tidak hanya pada pasar domestik,tapi juga global balance of power dan nilai-nilai juga institusi yang telah diterapkan oleh masyarakat dunia.

Hal ini, menyebabkan perusahaan teknologi multinasional yang bergerak dalam bidang inovasi teknologi sangat berpengaruh, sampai sejauh kekuatan ekonomi dan politik mereka setara atau bahkan melampaui suatu negara secara umumnya. Pada saat yang sama, hal tersebut mempersulit bagi pembuat kebijakan di semua tingkatan untuk mengikuti kecepatan dan perkembangan teknologi baru. Sifat transformative technology, jika dikombinasikan dengan munculnya aktor non-negara yang kuat akan membentuk kebijakan luar negeri dan geopolitik dengan cara baru. Misalnya, Artificial Intelligence dengan cepat menjadi medan pertempuran dalam keseimbangan kekuatan global yang terus bergeser, keamanan siber telah naik ke puncak agenda keamanan nasional, dan jaringan 5.0G telah menjadi masalah yang diperebutkan secara internasional. Seperti yang dikemukakan oleh Center for Long Term Cyber Security di UC Berkeley: "Geopolitik digital tidak lagi merupakan lapisan yang dilapisi pada geopolitik konvensional; digital menciptakan keberpihakan baru di antara aktor baru, dan bukan hanya negara bagian."

Bagi pemerintah yang hanya mengandalkan hubungan diplomatik dengan cara dan paradigma tradisional untuk membawa pulang pengetahuan, mempromosikan kepentingan dan melindungi nilainilai yang mereka bawa ke luar negeri, sepertinya itu sudah tidak cukup. Itulah mengapa dengan proposal ini kami menyediakan suatu gagasan bernama diplomasi digital yang menjadi salah batuan bagian dan wujud implementasi dari "Techplomacy". Saat ini, yang umum dilakukan oleh negaranegara dalam mewujudkan diplomasi digital dengan menggunakan website dan portal departemen luar negeri untuk menyebarkluaskan informasi dan kebijakan, menggunakan sosial media seperti Facebook, Twitter, Instagram untuk menyebarluaskan dan mengkampanyekan kebijakan luar negeri dan merespon isu-isu terkini terkait pada aktor hubungan internasional yang umumkan dilakukan searah (dari internal ke eksternal) dan sifatnya hanya membroadcast informasi, tidak ada informasi yang diolah dan di analisa dari eksternal ke internal.

Techplomacy hadir sebagai tindakan diplomasi mutakhir. Yang dirancang untuk menjembatani kesenjangan antara pemerintah dan industri teknologi. Techplomacy, tidak lagi ditentukan oleh aktoraktornya, melainkan oleh dinamika komunikasinya apakah pemerintah, non-pemerintah, atau publik. "Situs diplomatik" yang menempatkan diplomasi dalam ranah realitas sosial. Fenomena seperti isu kudeta Myanmar, kebijakan presiden terpilih Joe Biden dalam perihal yang condong global, dan sentimen anti-imigran adalah bagian dari konsekuensi tersebut. Karena itu penting bagi para diplomat untuk memahami dinamika situs diplomatik baru ini. Maka dengan itu, seorang techplomat ${ }^{l}$ perlu membangun jaringan dan mendiskusikan pandangan dan kebijakan, mendorong investasi, dan mempromosikan ekspor ke startup Silicon Valley, termasuk isu siber, dan kebijakan pengembangan yang menandakan wujud atau jenis diplomasi yang baru dan menyebarluaskan propaganda dan kebijakan dan menghalau sentiment negatif jika menimpa negaranya dari internet.

Saat ini, yang umum dilakukan oleh negara-negara dalam mewujudkan diplomasi digital dengan menggunakan website dan portal departemen luar negeri untuk menyebarkluaskan informasi dan kebijakan, menggunakan sosial media seperti Facebook, Twitter, Instagram, Youtube untuk menyebarluaskan dan mengkampanyekan kebijakan luar negeri dan merespon isu-isu terkini terkait pada aktor hubungan internasional yang umumkan dilakukan searah (dari internal ke eksternal) dan sifatnya hanya menyebarluaskan informasi, tidak ada informasi yang diolah dan di analisa dari eksternal ke internal dan sebaliknya.

Penelitian Techplomasi, merupakan solusi terkini bagi Pemerintah Indonesia saat ini, karena, satu dari beberapa negara yang semakin banyak menggunakan teknologi digital dalam diplomasi internasional, menurut survei, Indonesia menempati posisi ke-38 dari 209 negara di Digital Diplomacy Review 2017. Peringkat ini, menurun dibanding peringkat tahun lalu, ketika Indonesia 
menempati satu posisi lebih tinggi. Indonesia berada di belakang negara-negara Eropa yang memiliki teknologi tinggi seperti Prancis dan Inggris, juga negara-negara Asia seperti Jepang dan India. Namun, Indonesia berada di depan negara-negara Asia. Penelitian lainnya, dilakukan Universitas Gadjah Mada Center for Digital Society, menempatkan Indonesia di peringkat ke-9 di antara 203 negara untuk kegiatan diplomasi digital.

Denmark, yang pertama kali menggagas tentang konsep techplomacy sejak 2017. Inisiatif tersebut pertama kali diuraikan dalam Strategi Kebijakan Luar Negeri dan Keamanan Pemerintah Denmark tahun 2017-2018. Kebijakan tersebut melintasi kebijakan luar negeri dan keamanan, termasuk dunia maya, kebijakan pembangunan, promosi ekspor dan investasi, dan berbagai kebijakan sektor - serta lintas hubungan bilateral Denmark dengan negara lain dan di Uni Eropa dan forum multilateral. Informasi profiling aktor-aktor hubungan internasional yang ingin diketahui oleh setiap diplomat dengan bersumber awal dari informasi dari akses publik seperti internet dan sosial media. Dari informasi tersebut dibuat kategori, per-aktor, sektor atau bidang atau pembagian isu yang ingin di tarik dan dianalisa informasinya. Kata kunci bisa menggunakan "keyword", symantic, lexical analyst, tagar, \#tag, judul berita, Social Network Analyst (SNA), author, geolocation detection, dan sebagainya. Racangan desain sistem yang akan dikembangkan dalam penelitian ini terdiri dari dua modul utama, yaitu internal-to-external analyst systems dan external-to-internal analyst systems. Dua modul ini digunakan untuk mencrawler informasi dari internet dan sosial media terkait aktor hubungan internasional. Sumber berita/topik/isu/profil untuk sosial media dari Facebook, Instagram, Youtube dan Twitter. Sedangkan sumber lainya dari portal-portal berita resmi dari intergovernment organization, non government organization, government organization, multitransnational corporation, digital newspaper (Aljazeera, CNN, The Guardian, dsb).
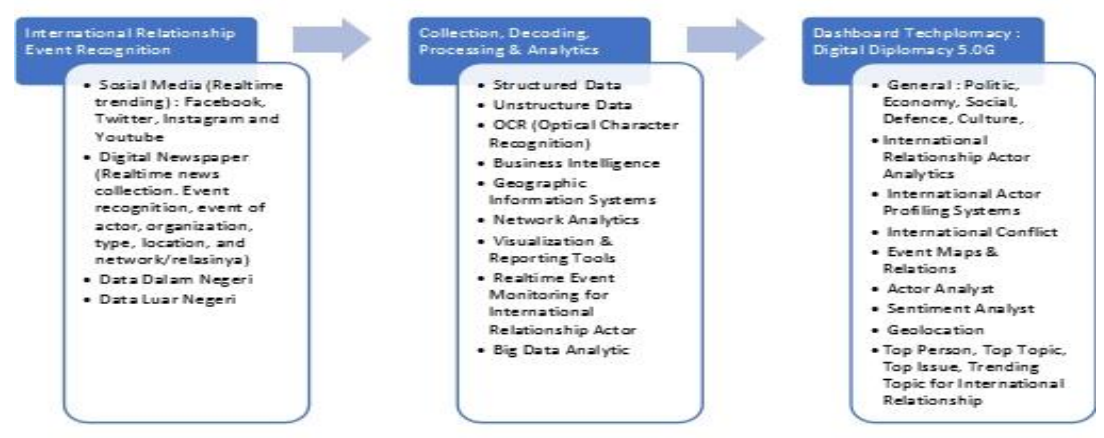

Gambar. 1.

Sistem Framework Techplomacy Menuju Digital Diplomacy 5.0G
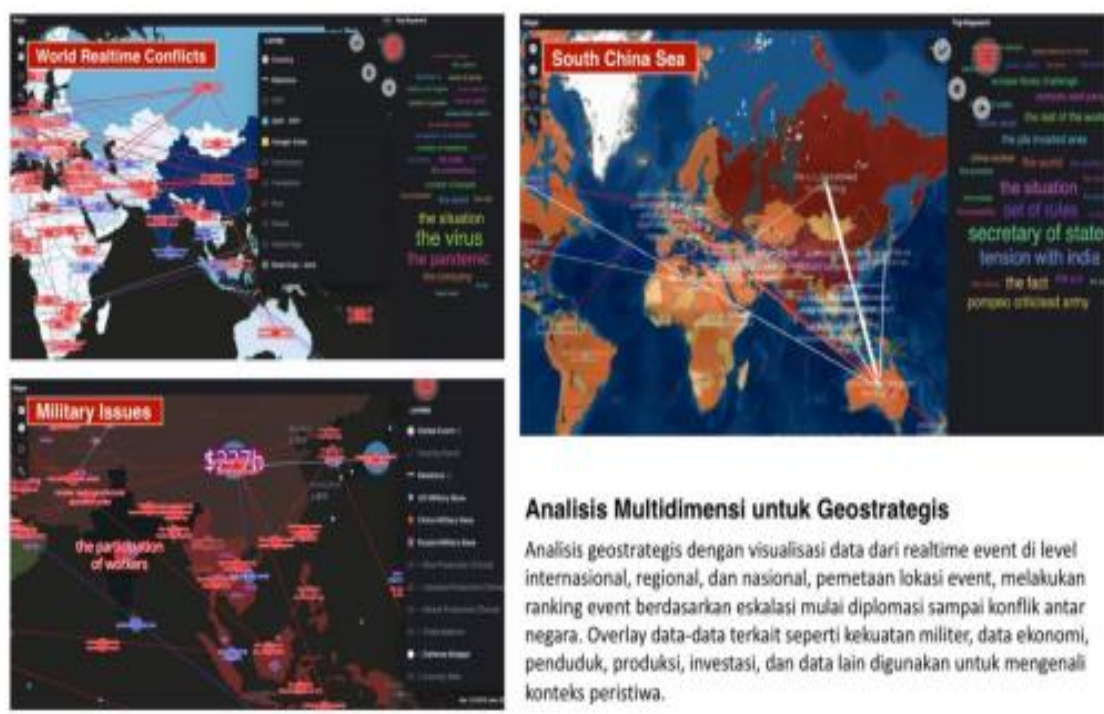

Analisis Multidimensi untuk Geostrategis

Analisis geostrategis dengan visualisasi data dari realtime event di level internasional, regional, dan nasional, pemetaan lokasi event, melakukan ranking event berdasarkan eskalasi mulai diplomasi sampai lonflik antar negara. Overlay data-data terkait seperti kekuatan militec, data ekonomi, penduduk, produksi, investasi, dan data lain digunakan untuk mengenali konteks peristiva.

Gambar.2.

Contoh Visual Analisis Tampilan Sistem 


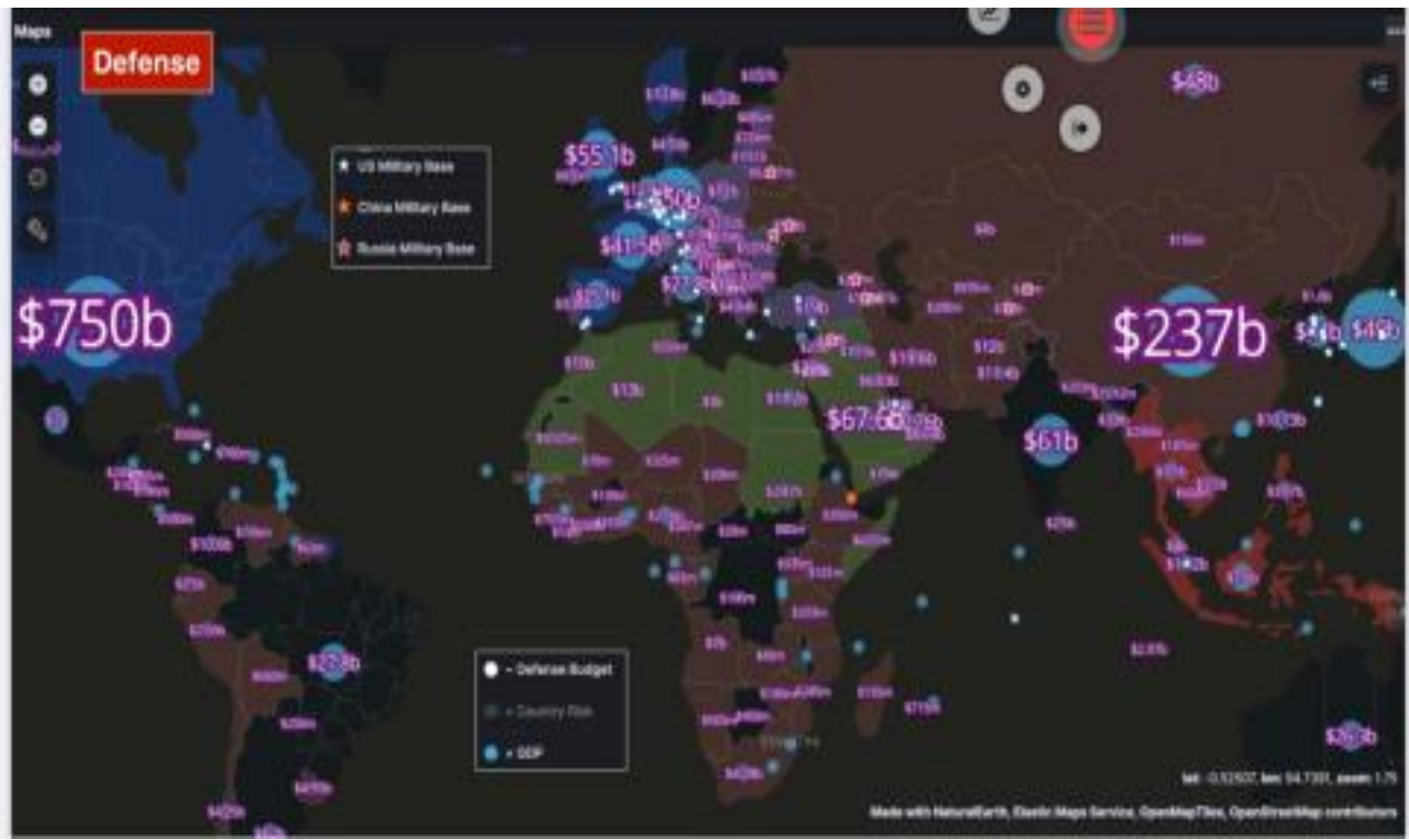

Gambar 3.

Contoh Tampilan Analyst Geolocation

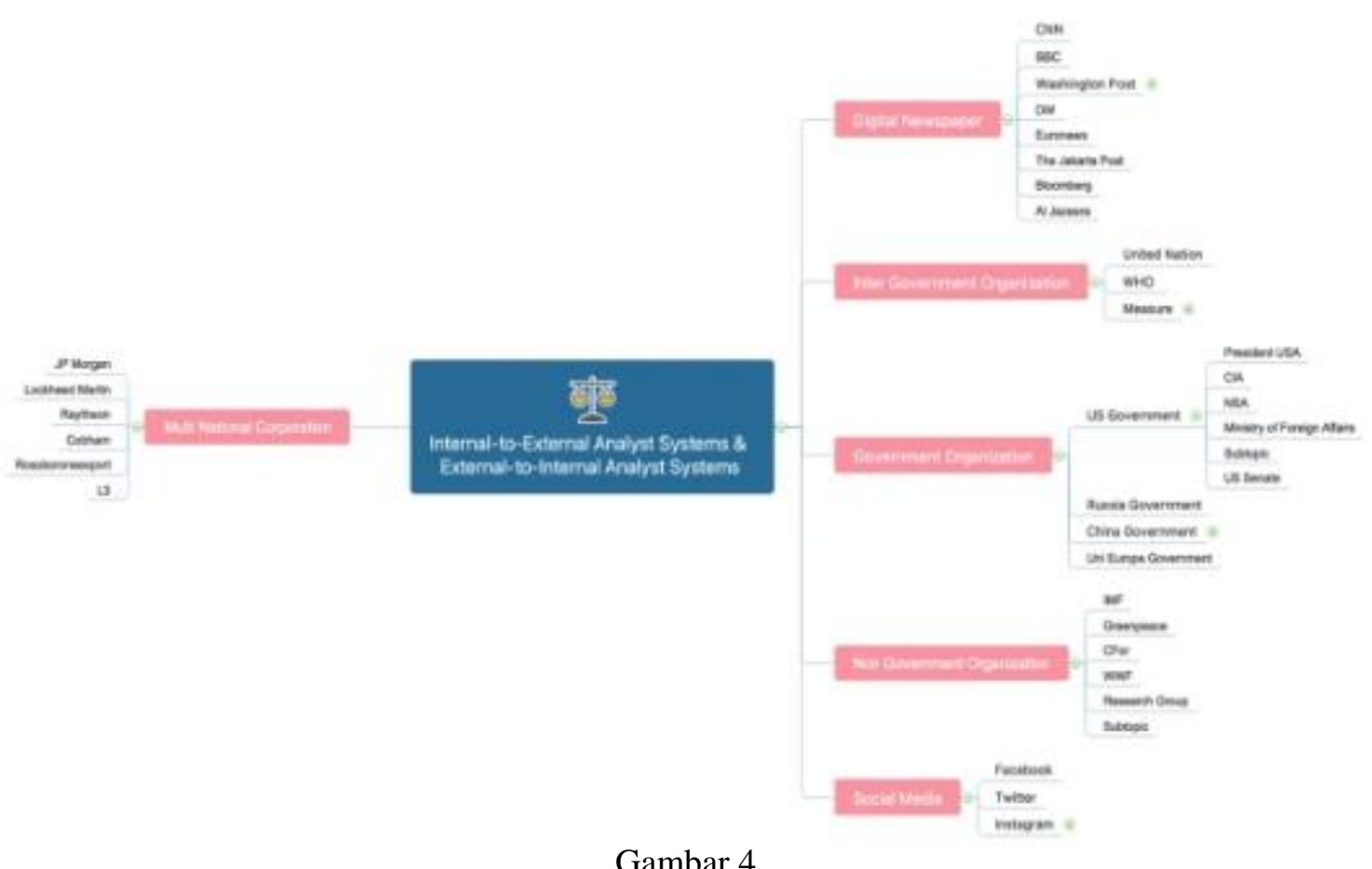

Gambar 4.

Eksternal \& Internal Analyst Systems 
Pihak-Pihak Yang Turut Andil: Pihak-pihak yang turun serta dan memiliki andil dalam penelitian ini adalah; (1) Pihak rektorat kampus Universitas Prof. Dr. Moestopo (Beragama); (2) Program Studi Hubungan Internasional Universitas Prof. Dr. Moestopo (Beragama); (3) Dosen pengampu penelitian ini; (4) Stakeholder lain yang dapat memberikan data, informasi serta keperluan suksesnya penelitian ini.

Langkah-Langkah Strategis: Penelitian dibagi menjadi beberapa tahapan.

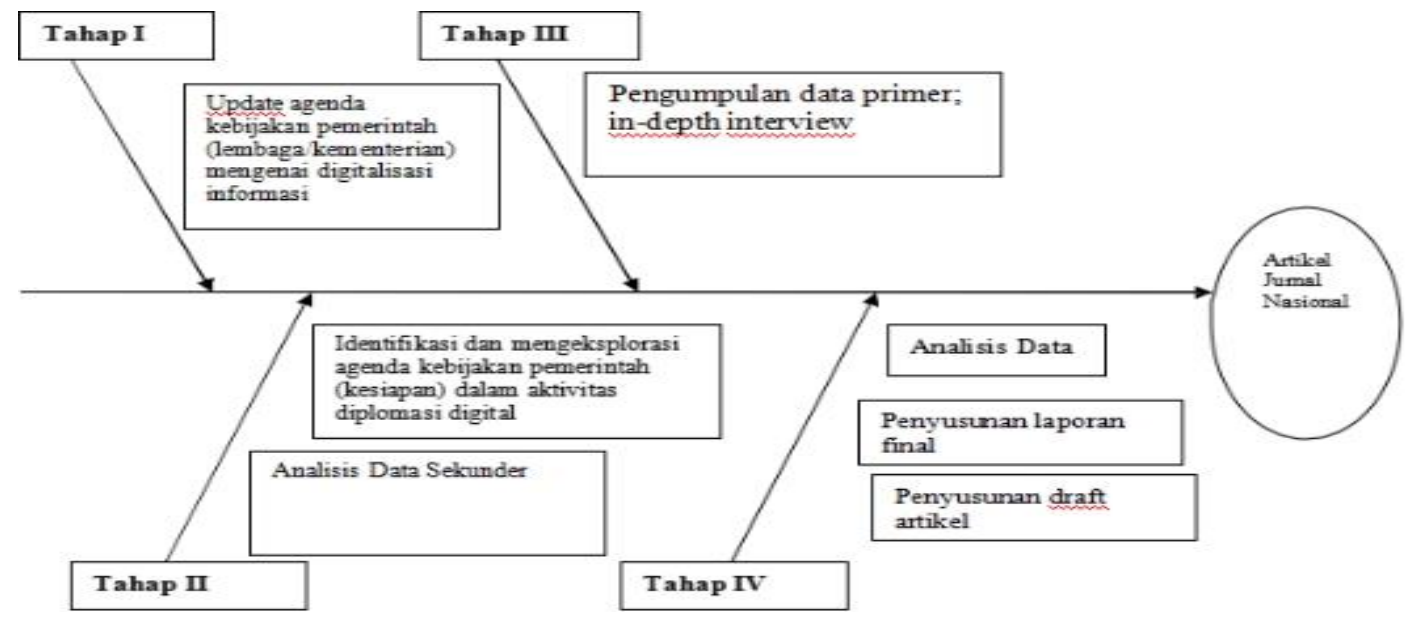

Gambar 5.

Tahapan Strategis Penelitian

\section{KESIMPULAN}

Gagasan yang penulis ajukan dalam penelitian ini adalah pertama membuat pemodelan untuk mendefinisikan, membagi sektor/bidang/topik terkait aktor hubungan internasional dan kemudian membuat keyword dan simantik dari setiap isu/topik yang akan menjadi model input dari setiap machine learning untuk mencrawling informasi dari internet dan sosial media. Pemodelan ini nantinya dapat digunakan oleh pihak manapun untuk mencrawling informasi terkait aktor hubungan internasional untuk tujuan penelitian, bank data jika sudah memiliki machine crawling sendiri.

Pembuktian dari gagasan yang diajuan yang sudah dalam bentuk pemodelan, maka penulis akan membuat pembuktian dengan membangun sistem crawling dengan menggunakan machine learning bahwa desain dan pemodelan yang dibuat dapat diimplementasikan dengan membuat sebuah prototipe yang implementatif.

Langkah merealisasikan penelitian ini terdiri dari tahapan-tahapan : (1) Pendefinisian dan penggolongan aktor-aktor hubungan internasional yang akan dibahas; (2) Pendefinisian dan penggolongan secara detail topik, sektor, bidang sosial, ekonomi, budaya, politik, hukum, pendidikan, kesehatan, pertahanan keamanan, energi, teknologi, pangan lingkungan, serta sosial budaya pariwisata yang akan dicrawling oleh machine learning; (3) Pendataan sumber informasi dari internet untuk digital newspaper yang akan dicrawling; (4) Interkoneksi server dengan pusat crawling data sosial media (Facebook, Twitter, Youtube, Instagram dan media online lain); (5) Development dan kustomisasi machine learning systems; (6) Instalasi di server crawling; (7) Crawling informasi sesuai dengan penggolonan aktor, topik, isu, bidang; (8) Penyajian data realtime.

Prediksi dampak gagasan ini jika dapat tereleasisasikan dengan baik, maka dapat memberikan dampak : (1) Diplomat dapat menggunakan sistem ini untuk menghimpun informasi terkait isu-isu aktor hubungan internasional, memiliki analisa sentimen positif dan sentimen negatif, geolocation sumber berita, lexical analyst, Social Network Analytst (SNA) atau pihak-pihak yang terkait dengan informasi dan berita; (2) Akademisi dapat memiliki informasi yang akurat dan update terkait aktoraktor hubungan internasional dan isu yang sedang trending di sosial media network, internet; (3) Terbentuknya bank data aktor hubungan internasional dan pembagian aktor, isu, topik, yang dapat 
diamati durasi trendingnya, respon isu dan aktor yang dapat dijadikan bahan referensi untuk sosialisasi kebijakan dan propaganda.

\section{Daftar Pustaka}

Adesina, O. S. (2016). Foreign Policy In An Era Of Digital Diplomacy. African Journal For The $\begin{array}{lllll}\text { Psychological Study Of Social Issues, } & 19(3), & 169-189 .\end{array}$ http://ajpssi.org/index.php/ajpssi/article/viewFile/198/pdf 150

Antara. (2017). Diplomasi Digital Kemenlu Perkuat Politik Luar Negeri http://www.mediaindonesia.com/news/read/114683/diplomasi-digital-kemenlu-perkuatpolitik-luar-negeri/2017-07-26 9 Februari 2021 Antara. 2017.

Balassa, B.. (1961). The Theory of Economic Integration. Homewood, Illinois: R.D. Irwin.

Bollier, D. (2003). The Rise Of Netpolitik. How the Internet Is Changing International Politics and Diplomacy. Washington: The Aspen Institute.

Corbin, Juliety/Strauss, Anselm. (2008). Basics of Qualitative Research. 3rd ed. London: Sage Publication.

Diplomasi Digital Kemenlu Perkuat Politik Luar Negeri, http://www.mediaindonesia.com/news/read/114683/diplomasi-digital-kemenlu- perkuat-politikluar-negeri/2017-07-26 diakses $\quad 9 \quad$ Februari 2021.http://kabar24.bisnis.com/read/20170517/15/654738/wamenlu-diplomasi-harus-jawabtantangan-digital

Dizard, W. (2001). Digital Diplomacy: U.S. Foreign Policy in the Information Age. London: Praeger.

Hocking Brian dan Jan Melissen. (July 2015). Diplomacy in the Digital Age. Clingendael Report. Diakses pada 10 Desember 2016, http://www.egmontinstitute.be/wpcontent/uploads/2015/07/DIPLO-IN-DIGITAL-AGE.-PDF.pdf

Mansbach, R W. International Relations and Information Technology, Encyclopedia of Life Support System (EOLSS), International Relations, Vol. II, http://www.eolss.net/sample-chapters/c14/e135-03-03.pdf.

Melissen. Jan (editor). (2005) The New Public Diplomacy. New York: Palgrave McMillan.

Nurudin. (2017). Perkembangan Teknologi Komunikasi. Jakarta: Rajawali Press.

Nawa Cita Presiden Joko Widodo (Jokowi) Jusuf Kalla (JK) 2014 - 2019 Unpublished document "Konsep White Paper/Book Diplomasi Digital” Rencana Strategis Kemlu 2015-2019.

Schmidt, Eric dan Cohen, Jared. (2013). The New Digital Age: Reshaping The Future of People, Nations, and Business, (New York: ALFREDA.KNOPF)

Snarr, M dan D. Neil Snarr. (2008). Introducing Global Issues. USA: Lynne Rienner Publisher

Sudjana. (2005). Metoda Statistika. Bandung: Tarsito

Syafputri, Ella. (April 2016). Masyarakat digital adalah masa depan Indonesia. Antara News, 22 April 2016. Diakses pada 9 Februari 2021 http://www.antaranews.com/berita/556730/masyarakatdigital-adalah-masa-depan-Indonesia.

Yahya, T. (April 2016). Digital Diplomacy, Sebuah Kebutuhan Mendesak. Detik News, 22 April 2016. Diakses9 Februari 2021, http://news.detik.com/kolom/3194614/ltigtdigitaldiplomacyltigt-sebuah-kebutuhan-mendesak. 